\title{
Foreign Exchange Reserve Accumulation, Domestic Stability, and Foreign Exchange Policy: The Case of China (2001-2010)
}

\author{
Xin Wang ${ }^{1}$, Aric Krause ${ }^{2} \&$ Christopher S. P. Tong ${ }^{2}$ \\ ${ }^{1}$ College of Economics, Nankai University, Tianjin, People's Republic of China \\ ${ }^{2}$ Bill and Vieve Gore School of Business, Westminster College, Salt Lake City, Utah, USA \\ Correspondence: Christopher Tong, Bill and Vieve Gore School of Business, Westminster College, 1840 South \\ 1300 East, Salt Lake City, Utah, 84105, USA. Tel: 1-801-832-2630. E-mail: ctong@westminstercollege.edu
}

Received: July 24, $2012 \quad$ Accepted: October 12, $2012 \quad$ Online Published: October 23, 2012

doi:10.5539/ijef.v4n12p39 URL: http://dx.doi.org/10.5539/ijef.v4n12p39

\begin{abstract}
Since reform of the foreign exchange management system in 1994, China's foreign trade has been expanding at a fantastic pace. The resulting trade surplus has surpassed that of nearly any other economy and at the same time brought along increasing international pressure and criticism to revalue the Chinese currency. While much of the existing literature has focused on questions such as whether or not the RMB should be revalued and how its appreciation will improve the imbalance of the global economy, limited attention has been paid to the impact of (a) the changes in the RMB exchange rate and (b) the accumulation of foreign exchange reserve on the domestic economy of China - and ultimately the resulting economic growth of China. This study aims to fill this gap in the literature by studying the relationships among the exchange rate, foreign exchange reserve, and general price level of China, and draws feasible recommendations on China's future exchange rate policy.
\end{abstract}

Keywords: China, inflation, Foreign Reserve Deposit, exchange rate, cointegration, VAR

\section{Introduction}

Since reform of the foreign exchange management system in 1994, China's foreign trade has been expanding at a fantastic pace; the resulting trade surplus has surpassed that of nearly any other economy and continues to rise. On one hand, China's international trade surplus has brought along increasing international pressure and criticism from its trade partners to revalue the Chinese currency, the Renminbi (RMB). In 1994, the Chinese Central Government decided, after a series of adjustments over 10 years, to unify its two exchange rates - the official exchange rate and the internal settlement rate - at the then prevailing secondary market price of $8.7 \mathrm{RMB}$ per US dollar. This adjustment, shown in Figure 1, represented a marked policy change which was frequently described as a 50 percent instant devaluation of the RMB. (Note 1) This adjustment was believed to be at a point at or near equilibrium, given capital account controls in place at the time, according to Fernald et. al. (1998).

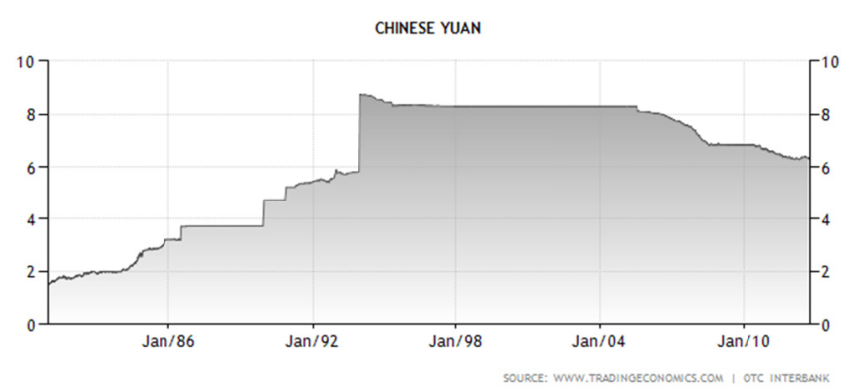

Figure 1. Chinese Yuan to Dollar Exchange Rate

Source: Bank of China 2012. 
The immediate consequences of this action were that the export of China increased rapidly by 32 percent and 23 percent, respectively, in 1994 and 1995. China has maintained trade surpluses ever since 1994 as shown in Figure 2 .

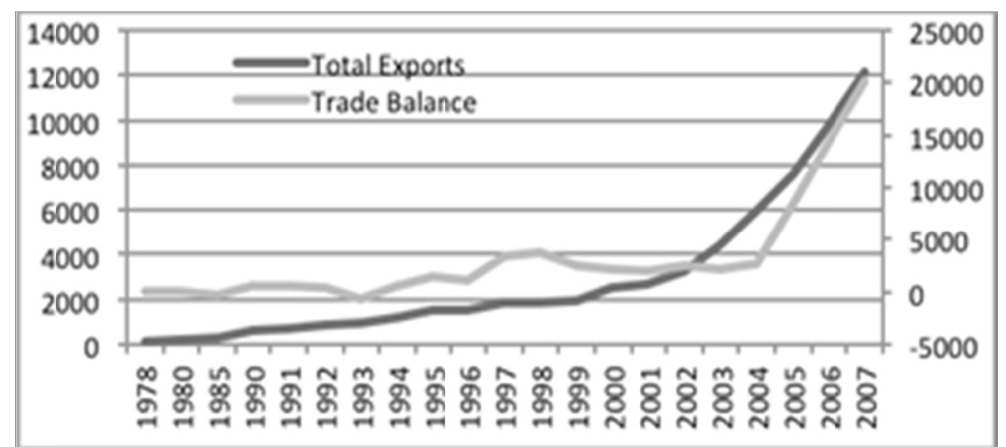

Figure 2. China Trade Balance, 1978-2007

Trade balance scale is shown on the right axis

Many trade partners of China believe that they have been adversely affected by the rapid development of the Chinese economy as well as China's foreign exchange policy. According to Morrison (2008), the United States complained about the undervalued RMB as the major cause of the large bilateral U.S. trade deficit with China and as a result, the significant decline of employment in the U.S. manufacturing sector over the past few years. Yang, Yin, and He (2007) mention Japan's accusations that China's policies have served to export deflation, further weakening non-China economic growth.

The fact that the share of the processing trade in its total trade surplus stood at 105 percent in 2006 invited further criticisms and built an image that China was effectively importing surplus from its neighboring countries. (Note 2) In addition, many emerging Asia economies were also dissatisfied with China's exchange rate policy because they were facing a competitive challenge raised not only by China's low labor costs, but also the upgraded skill level of China's exports. China was exporting products with an increasingly high degree of sophistication in direct competition with its regional trading partners, accelerating the erosion of considerable competitive and comparative advantages throughout the region.

On the other hand, China's export-oriented policy contributed tremendously to the fast growth of its economy and the sizable surplus in both its current and capital accounts, resulting in the rapid accumulation of foreign exchange reserves of China. In 2007, China's foreign exchange reserve was about US\$ 1,528.2 billion, but it reached the alarming level of US\$2,847.3 billion by the end of 2010. While the foreign exchange reserve only accounted for about 15.6 percent of China's GDP in 1999, it became almost 50 percent by the end of 2010. Today, China is the world's largest foreign exchange reserve holder.

Recently, the RMB exchange rate against the US dollar has fallen from 8.27 in July 2005 to the recent level of 6.39 in April 2012. As suggested by Kumhof, Li and Yan (2007), this change in the RMB's value is a concern to the Chinese Central Government because excessive rather than insufficient foreign exchange reserve is often accompanied by exchange rate appreciation and higher domestic inflation.

Much of the existing literature has focused on questions such as whether or not the RMB should be revalued, what kind of reform in the currency regime would be most suitable for China, and how the appreciation of the RMB will improve the imbalance of the global economy. Limited attention has been given to the impact of the changes in the RMB exchange rate and the accumulation of foreign exchange reserve on the domestic economy of China.

This study aims to fill this gap in the literature by conducting an empirical research on the relationships among the exchange rate, foreign exchange reserve, and general price level of China, and draws feasible recommendations on China's future exchange rate policy that would result in both steady economic growth for China and am improving atmosphere and working relationship for global economic cooperation between China and its trading partners. 
The paper proceeds as follows. Section two specifies both a theoretical and an estimation model for the study. Section three offers the empirical results and explanations, section four draws conclusions and provides policy recommendations.

\section{Methodology and Data}

\subsection{Theoretical Model}

The impacts of the exchange rate, the amount of money circulating in the economy, and the accumulation of foreign reserve on both inflation and unemployment are usually generated through the good market, the capital market, and the money market. We will adopt the model of Chen and He (2009), which itself is an extension of the open market macroeconomic model proposed by Mundell and Fleming (1963), and includes an IS, an LM, and BP curves, to empirically examine the relationships of the variables under study and derive conclusion on the exchange rate policy for the Chinese currency. It is true that this model has its weaknesses such as the lack of a clear micro foundation and the difficulty in assessing the welfare implication of the model because there are no agents in the set-up. However, it is still being used here because of its simplicity for estimation and intuitive policy implications. In addition, as claimed by Fischer (2008), this model is preferred because of its tractability, flexibility, and applicability.

Excluding the net balance and the discrepancy terms, the national income accounting identity suggests that the sum of the current account balance $(C A B)$, the capital and financial account balance $(C F A B)$ and the reserve account balance $(R A B)$ of a country equals to zero, i.e.,

$$
C A B+C F A B+R A B=0
$$

Since the change in the amount of total foreign reserve $(\triangle F R)$ makes up a dominant proportion of the RAB in China, Equation (1) can therefore be rewritten as:

$$
C A B+C F A B=\triangle F R
$$

where $\triangle F R$ is the annual change in the foreign reserve instead of its accumulation over the years. Equation (2) simply states that any change in the current account or the capital and financial account will lead to a change in the foreign reserve of a country.

If the current account and the capital and financial accounts of a country continue to experience surplus, like the case in China over the last twenty years, then to stabilize the exchange rate the government must purchase foreign currencies through its central bank, which in turn will result in an increase in the amount of foreign reserve of the country. Following the increase in the foreign reserve, i.e., when $\triangle F R>0$, the monetary base and the total amount of money circulating in the country will also increase. If the total money supply is greater than the total money demand, then the amount of money available is greater than the money required for economic development and the logical consequence is inflation. Therefore Equation (2) provides the link between the activities in the international sector and inflation of a country through the mechanism mentioned above.

Exchange rate will also affect the general relative price level $(P)$ of a country through both direct and indirect channels. When the exchange rate changes, it will affect the prices of all the imported commercial goods and hence directly lead to the change in $P$ of the country.

Indirectly, when the exchange rate varies, it will affect the cost of production of all goods produced at home that use imported materials, which in turn will again impact $P$. The net effect of the change in exchange rate on $P$ whether it goes up (inflation) or goes down (deflation) - is dependent upon the combined effects of: (a) the direct channel, (b) the indirect channel, and (c) the forces that are transmitted through the change in the foreign reserve as discussed earlier.

When the aggregate demand (AD) equals to the aggregate supply (AS) in an open market macroeconomics model that includes an international sector, the equilibrium can formally be written as:

$$
Y=\bar{C}+c\left(1-t_{0}\right) Y+\bar{I}-g r+\bar{G}+\bar{X}-(\bar{M}+m Y)
$$

Where $Y$ denotes national income, $t_{\mathrm{o}}=$ tax rate, $r=$ nominal interest rate, $c, g$, and $m$ are the marginal propensity of consumption, investment, and import, respectively, and $\bar{C}, \bar{I}, \bar{G}, \bar{X}$, and $\overline{\mathrm{M}}$ are the autonomous amounts of consumption, gross investment, government expenditures, exports, and imports, respectively. After re-arranging the terms, then we can rewrite Equation (3) as follows: 


$$
Y=\frac{\bar{C}+\bar{I}+\bar{G}+\bar{X}+\bar{M}}{1-c\left(1-t_{0}\right)+m}-\frac{g}{1-c\left(1-t_{0}\right)+m} r
$$

If we let $\bar{E}=\frac{\bar{C}+\bar{I}+\bar{G}+\bar{X}+\bar{M}}{1-c\left(1-t_{0}\right)+m}$, and $\mathrm{g}^{\prime}=\frac{g}{1-c\left(1-t_{0}\right)+m}$, then Equation (4), i.e., the goods market equilibrium, can be simplified and rewritten as:

$$
Y=\bar{E}-g^{\prime} r
$$

When the money market is at equilibrium, i.e., when the total money demand equals to the total money supply, it can formally be written as:

$$
r=\frac{M}{P h}+\frac{k}{h} Y
$$

where $M$ denotes the total nominal money supply and $k$ and $d$ are the coefficients that show the response of money demand to the change in income and the change in interest rate, respectively.

Assuming that international financial capital is free to flow in and out of the country, the equilibrium condition of the balance of payments as suggested by Mundell and Fleming can formally be written as:

$$
B P=\delta_{1} E R-\delta_{2} Y+\delta_{3} Y^{*}+\lambda\left(r-r^{*}\right)
$$

After re-arranging terms, Equation (7) can be re-written as:

$$
r=r^{*}+\frac{B P-\delta_{1} E R+\delta_{2} Y-\delta_{3} Y^{*}}{\lambda}
$$

Where $B P$ denotes the balance of payments, $E R$ is the nominal exchange rate, $Y^{*}$ is the level of global income and $r^{*}$ is the level of global interest rate. Here, both the level of global income and global interest rate are assumed to be exogenous variables. $\delta_{1}, \delta_{2}$, and $\delta_{3}$ in Equation (8) are the response coefficients of the balance of payment to the change in exchange rate, domestic income level, and global income level, respectively. $\lambda$ represents the degree of international capital mobility. Substituting Equations (5) and (6) into Equation (8), isolating the variable $P$ on one side, simplifying and re-arranging, a formal expression of the general price level can be then formally written as:

$$
P=\frac{M * \lambda}{\lambda k\left(\bar{E}-g^{\prime} r\right)-\lambda h r^{*}-h\left[B P-\delta_{1} E R+\delta_{2}\left(\bar{E}-g^{\prime} r\right)-\delta_{3} Y^{*}\right]}
$$

The result of taking the first derivative of the logarithmic form of Equation (9) is:

$$
\frac{P^{\prime}}{P}=\frac{M^{\prime}}{P}+\frac{h-\delta_{1} h}{\lambda k\left(\bar{E}-g^{\prime} r\right)-\lambda h{ }^{*}-h\left[\Delta F R-\delta_{1} E R+\delta_{2}\left(\bar{E}-g^{\prime} r\right)-\delta_{3} Y^{*}\right]}
$$

Since the currency performance of BP is usually reflected in changes of the foreign reserve deposit; therefore, the term $B P$ in Equation (9) is replaced by $\triangle F R$ in Equation (10). If $M$ is assumed to be an exogenous variable, then what Equation (10) suggests is that fluctuations in both the exchange rate $(E R)$ and the foreign reserve deposit $(F R)$ will certainly affect $P$, which is a key indication of the macroeconomic stability of the country and also a major concern of the Chinese Central Government.

\subsection{Estimation Methodology}

The Vector Cointegration and Vector Error Correction Model (VECM) will be used here because of its capacity of simultaneously estimating the short-run dynamic and the long-run relationships of the variables. Assuming $P$, $E R$, and $F R$ are all endogenous variables, we can transform Equation (10) into a system of equations as follows:

$$
\Delta P_{t}=\sum_{i=1}^{k-1} \theta_{1 i} \Delta P_{t}-i+\sum_{i=1}^{k-1} \phi_{1 i} \Delta E R t-i+\sum_{i=1}^{k-1} \delta_{1 i} \Delta F R t-i+\gamma_{1 i} \hat{Z}_{t-1}+\mu_{1}+V_{1 t}
$$




$$
\begin{aligned}
\Delta E R_{t} & =\sum_{i=1}^{k-1} \theta_{2 i \Delta P} \Delta P_{t} i+\sum_{i=1}^{k-1} \phi_{2 i} \Delta E R t-i+\sum_{i=1}^{k-1} \delta_{2 i \Delta} \Delta F R t-i+\gamma_{2 i} \hat{Z}_{t-1}+\mu_{2}+V 2 t \\
\Delta F R_{t} & =\sum_{i=1}^{k-1} \theta_{3 i \Delta P t-i}+\sum_{i=1}^{k-1} \phi_{3 i} \Delta E R t-i+\sum_{i=1}^{k-1} \delta_{3 i \Delta} \Delta F R t-i+\gamma_{3 i} \hat{Z}_{t-1}+\mu_{3}+V 3 t
\end{aligned}
$$

where $k$ is the optimal number of lags that will generate white noise, $\mu_{\mathrm{i}}(\mathrm{i}=1,2,3)$ is the constant term, and $\mathrm{V}_{\mathrm{i}}$ is the long-run random disturbance term that is assumed to be idd $\sim \mathrm{N}(0, \Sigma)$. The error correction term (EC), $\hat{Z}_{t-1}$, in each equation is the lagged value of the long-run residual that is estimated by the Ordinary Least Squares (OLS). At a more intuitive level, the presence of $\hat{Z}_{t-1}$ in the equations reflects the correction of the short-run disequilibrium of the variables by their long-run relationship.

To distinguish between stationarity by linear combination of the variables, i.e., cointegration, and by differencing of the variables, the whole system of equations can be represented by a VECM as:

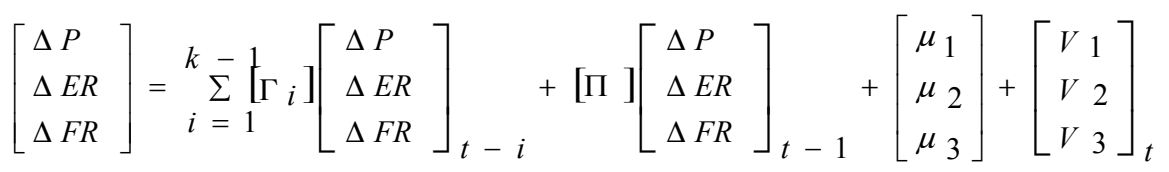

In Equation (12), the matrix $\left[\Gamma_{\mathrm{i}}\right]$ summarizes the short-run dynamics of the variables, and $[\Pi]$, the long-run impact matrix, provides information on the long-run co-movement of the variables. The number of cointegrating vectors is determined by the rank of the long-run impact matrix. In the situation where $[\Pi]$ is a null matrix, its rank is zero and implies no long-run relationship between the variables and so the whole system of equations will be reduced to a first difference Vector Autoregressive (VAR) model.

This study covers the period from the first quarter of 1994 to the last quarter of 2010 and hence the sample size is 68. Here, $P$ stands for China's domestic inflation rate and its information is extracted from different issues of the Statistical Yearbook of China; ER is the exchange rate of RMB per US dollar and its data is obtained from the website of State administration of Exchange Control (Note 3); FR represents China's foreign exchange reserve and its data is collected from website of the People's Bank of China (PBoC) (Note 4). Lastly, $M$ is the broader classification of the money supply, M2, which includes M1, savings deposits by urban and rural residents, time deposits, deposits in foreign currencies, and trust funds deposits, all of which is collected from the website of the PBoC.

\section{Empirical Results}

Since this study utilizes time series data, it is crucial that we test the null hypothesis that a unit root exits for each of the variables in natural logarithm. To do that, we have applied the ADF test developed by Dickey and Fuller $(1979,1981)$. Table 1 reports the statistics of the unit root test under three different testing models: (1) model without intercept or trend $(\tau),(2)$ model with intercept $\left(\tau_{\mu}\right)$, and (3) model with both intercept and trend $\left(\tau_{\tau}\right)$.

Table 1. Univariate Unit Root Test

\begin{tabular}{cccc}
\hline Variable & $\boldsymbol{\tau}$ & $\boldsymbol{\tau}_{\boldsymbol{\mu}}$ & $\boldsymbol{\tau}_{\boldsymbol{\tau}}$ \\
\hline $\boldsymbol{\operatorname { l n } P}$ & $1.5585(-3.4656)^{\mathrm{a}}$ & $-0.0028(-2.8326)$ & $-2.0576(-2.7833)$ \\
$\ln \boldsymbol{E}$ & $-2.2990(-5.3424)$ & $1.3957(-5.9915)$ & $-0.1910(-6.1922)$ \\
$\ln \boldsymbol{M}$ & $20.2237(-1.4801)$ & $-1.2 .1811(-5.2000)$ & $-4.3354(-5.1772)$ \\
$\ln \boldsymbol{F} \boldsymbol{2 . 7 2 7 7 ( - 2 . 0 8 5 1 )}$ & $-0.8070(-3.7701)$ & $-2.4083(-3.7646)$ \\
$\mathbf{C V ~ ( 5 \% ) ^ { \mathrm { b } }}$ & -1.9463 & -2.9100 & -3.4878 \\
\hline
\end{tabular}

${ }^{a}$ The values in parentheses are the test-statistics of the first difference of the variables.

${ }^{\mathrm{b}} \mathrm{CV}(5 \%)$ is the critical value at the $5 \%$ significance level.

The results indicate that all variables, except the natural logarithm of the nominal exchange rate $(\ln E R)$, are non-stationary at the level term when the test equation is modeled without a trend and a constant term. On the other hand, the test statistics obtained from the same model for the first difference of all the variables, except the natural $\operatorname{logarithm}$ of the total money supply $(\ln M)$, are all statistically significant at the 5 percent level. When tested with either an intercept or both an intercept and a trend term, the test statistics for the first difference of all the variables, except the natural logarithm of the general price level $(\ln P)$, is statistically significant. 
To ensure the variables of our regression model are appropriately chosen, we followed the procedure of Toda and Yamamoto (1995) to test for the Granger causality between $\ln P$ and each of the independent variables. Table 2 reports the appropriate maximum lag length for the variables in each of VAR models and its corresponding statistic based on the Akaike information criterion (AIC) selection method.

Table 2. Appropriate Maximum Lag Length in VAR

\begin{tabular}{ccc}
\hline Variables & Lag Order & AIC Statistics \\
\hline $\ln P, \ln E R$ & 7 & -13.5274 \\
$\ln P, \ln F R$ & 9 & -11.0527 \\
$\ln P, \ln M$ & 7 & -12.3310 \\
\hline
\end{tabular}

Note: The number of observations in each model is 58 and a constant term is included in each model as an exogenous variable.

The results suggest that seven is the most appropriate number of lags for three of the four VAR models. Table 3 gives the Lagrange Multiplier (LM) test results on the serial correlation of the residuals obtained from the four VAR models.

Table 3. LM Test Results on Serial Correlation of Residuals

\begin{tabular}{|c|c|c|c|c|c|c|c|c|}
\hline \multicolumn{3}{|c|}{$\ln P, \ln E R$} & \multicolumn{3}{|c|}{$\ln P, \ln F R$} & \multicolumn{3}{|c|}{$\ln P, \ln M$} \\
\hline Lag & LM-Statistic & Prob. & Lag & LM-Statistic & Prob. & Lag & LM-Statistic & Prob. \\
\hline 1 & 0.299544 & 0.9898 & 1 & 0.299544 & 0.9898 & 1 & 0.845073 & 0.9323 \\
\hline 2 & 5.201069 & 0.2673 & 2 & 5.201069 & 0.2673 & 2 & 2.349384 & 0.6718 \\
\hline 3 & 6.005851 & 0.1987 & 3 & 6.005851 & 0.1987 & 3 & 1.2861 & 0.8637 \\
\hline 4 & 3.787828 & 0.4355 & 4 & 3.787828 & 0.4355 & 4 & 3.432295 & 0.4882 \\
\hline 5 & 3.829673 & 0.4295 & 5 & 3.829673 & 0.4295 & 5 & 1.066312 & 0.8996 \\
\hline 6 & 1.056874 & 0.9011 & 6 & 1.056874 & 0.9011 & 6 & 11.56071 & 0.0209 \\
\hline 7 & 2.868144 & 0.5801 & 7 & 2.868144 & 0.5801 & 7 & 1.833995 & 0.7663 \\
\hline 8 & 3.360971 & 0.4993 & 8 & 3.360971 & 0.4993 & 8 & 2.155169 & 0.7072 \\
\hline 9 & 7.697049 & 0.1033 & 9 & 7.697049 & 0.1033 & 9 & 3.915808 & 0.4175 \\
\hline 10 & 6.170499 & 0.1868 & 10 & 6.170499 & 0.1868 & & & \\
\hline
\end{tabular}

Note: Probabilities are obtained from from the $\chi^{2}$ distribution with $\mathrm{df}=4$.

Since there are only two endogenous variables included in each of the VAR models, the degree of freedom (df) for each test is $2^{2}=4$ and the test statistic is distributed as a $\chi^{2}$ distribution. As indicated in the results, almost all the test statistics obtained are smaller than the critical value and therefore fail to reject the null hypothesis that there is no serial correlation in the residuals of the VAR models. These conclusions validate that the VAR models are correctly specified.

Table 4. Johansen Cointegration Test

\begin{tabular}{|c|c|c|c|c|c|}
\hline & $\begin{array}{c}\text { Trace Statistic } \\
\text { for } r=0\end{array}$ & $\begin{array}{c}\text { Trace Statistic } \\
\text { for } \leq 1\end{array}$ & $\begin{array}{l}5 \% \mathrm{CV} \\
\text { for }=0\end{array}$ & $\begin{array}{l}5 \% \mathrm{CV} \\
\text { for } r \leq 1\end{array}$ & Conclusion \\
\hline $\ln P, \ln E R$ & 15.0539 & 0.2355 & 15.4947 & 3.8417 & no cointegration \\
\hline $\ln P, \ln F R$ & $22.1051 *$ & 1.9527 & 15.4947 & 3.8417 & 1 cointegration equation \\
\hline \multirow[t]{2}{*}{$\ln P, \ln M$} & 14.6225 & 4.8008 & 15.4947 & 3.8417 & No cointegration \\
\hline & $\begin{array}{c}\text { Max-Eigen } \\
\text { statistic for } \\
r=0\end{array}$ & $\begin{array}{c}\text { Max-Eigen } \\
\text { statistic for } \\
r \leq 1\end{array}$ & $\begin{array}{c}5 \% \mathrm{CV} \\
\text { for } r=0\end{array}$ & $\begin{array}{l}5 \% \mathrm{CV} \\
\text { for } r \leq 1\end{array}$ & Conclusion \\
\hline $\ln P, \ln E R$ & $14.8185^{*}$ & 0.2355 & 14.2646 & 3.8415 & 1 cointegration equation \\
\hline $\ln P, \ln F R$ & $20.1524 *$ & 1.9527 & 14.2646 & 3.8415 & 1 cointegration equation \\
\hline $\ln P, \ln M$ & 9.8217 & 4.8008 & 14.2646 & 3.8415 & No cointegration \\
\hline
\end{tabular}

Note: $r=$ Number of cointegration equation. * Statistically significance at the 5 percent level. 
The results of the Johansen cointegration test (Johansen 1988, 1981; Johansen \& Juselius 1990) for each pair of the variables in the VAR model are reported in Table 4. Although a test on cointegration is not a required step in the Granger causality test, it, however, provides a cross-check on the validity of the test results obtained later. The Johansen's Trace Test and Maximum Eigenvalue Test both indicate that the pair of variables $-\ln P$ and $\ln F R$ - are in fact cointegrated. Although the results from both tests consistently indicate that $\ln P$ and $\ln M$ are not cointegrated, they are conflicting with respect to testing the existence of a long-run relationship between $\ln P$ and $\ln E R$. However, it is logical to conclude that inflation and exchange rate in China do move together in the long-run because (1) the difference between the Trace test statistic (15.0539) and its corresponding 5 percent critical value (15.4947) is trivial, and (2) the estimated cointegrating vector is statistically significant and provides interpretable relationship between the variables.

The results of the Granger causality test reported in Table 5 are consistent with Johansen's cointegration test results discussed above. That is, a one-way causality between a pair of variables is shown to exist when they are reported to be cointegrated in Table 4.

Table 5. Granger Causality Test

\begin{tabular}{lccc}
\hline \multicolumn{1}{c}{ Null Hypothesis: } & Obs & Chi-Square Statistic & Probability \\
\hline $\ln \boldsymbol{E} \boldsymbol{R}$ does not Granger Cause $\ln \boldsymbol{P}$ & 61 & 8.4368 & 0.2957 \\
$\ln \boldsymbol{P}$ does not Granger Cause $\ln \boldsymbol{E} \boldsymbol{R}$ & 61 & 25.9120 & $0.0037^{* *}$ \\
$\ln \boldsymbol{F} \boldsymbol{R}$ does not Granger Cause $\ln \boldsymbol{P}$ & 59 & 18.6658 & $0.0282^{* *}$ \\
$\ln \boldsymbol{P}$ does not Granger Cause $\ln \boldsymbol{F}$ & 59 & 13.2833 & 0.1502 \\
$\ln \boldsymbol{M}$ does not Granger Cause $\ln \boldsymbol{P}$ & 61 & 15.4840 & $0.0303^{* *}$ \\
$\ln \boldsymbol{P}$ does not Granger Cause $\ln \boldsymbol{M}$ & 61 & 18.6735 & $0.0093^{* *}$ \\
\hline
\end{tabular}

Note: * Statistically significant at the $10 \%$ level. ${ }^{* *}$ Statistically significant at the $5 \%$ level

The results also report a two-way causality between the variables $\ln M$ and $\ln P$; however, since these variables are not cointegrated, a cross-check is not feasible. Even though the results fail to reject the null hypothesis that $\ln$ ER does not Granger cause $\ln P$, they certainly do not imply that $\ln P$ and $\ln E R$ are independent of each other.

Table 6 reports both the estimated short-run dynamics and the long-run steady state relationship between the dependent and the independent variables obtained from the VECM. Since the total nominal money supply, $M$, is assumed to be an exogenous variable in Equation (10), it is also included in the VAR model as an exogenous variable. The results in Table 6 are obtained in three steps. First, a VAR model was estimated and the optimal number of lags was determined to be six, based on meeting four of the six selection criteria. Second, the Trace statistic of the Johansen's cointegration test indicates that there is one cointegrating vector between the variables. Third, the VECM as shown in Equation (12) was estimated with $\ln M$ included as exogenous variables and the estimation results are reported in Table 6. 
Table 6. Vector Error Correction Estimates

\begin{tabular}{|c|c|c|c|}
\hline Cointegrating Eq: & CointEq1 & & \\
\hline $\ln P(-1)$ & 1.000000 & & \\
\hline $\ln E R(-1)$ & $\begin{array}{c}0.730635 \\
(0.11836) \\
{[6.17304]}\end{array}$ & & \\
\hline$\overline{\ln F R(-1)}$ & $\begin{array}{c}-0.102591 \\
(0.02665) \\
{[-3.84990]}\end{array}$ & & \\
\hline $\mathrm{C}$ & -6.033439 & & \\
\hline Error Correction: & D(LNP) & $\mathrm{D}(\mathrm{LN} E R)$ & D(LNFR) \\
\hline CointEq1 & $\begin{array}{c}-0.142900 \\
(0.06629) \\
{[-2.15575]}\end{array}$ & $\begin{array}{c}-0.166028 \\
(0.06953) \\
{[-2.38799]}\end{array}$ & $\begin{array}{c}0.311379 \\
(0.24029) \\
{[1.29586]}\end{array}$ \\
\hline $\mathrm{D}(\ln P(-1))$ & $\begin{array}{c}0.507195 \\
(0.13733) \\
{[3.69338]}\end{array}$ & & \\
\hline $\mathrm{D}(\ln P(-4))$ & $\begin{array}{l}0.599202 \\
(0.12794) \\
{[4.68333]}\end{array}$ & $\begin{array}{c}-0.358283 \\
(0.13420) \\
{[-2.66986]}\end{array}$ & \\
\hline $\mathrm{D}(\ln P(-5))$ & $\begin{array}{c}-0.487113 \\
(0.13807) \\
{[-3.52809]}\end{array}$ & $\begin{array}{c}0.318872 \\
(0.14481) \\
{[2.20195]}\end{array}$ & \\
\hline$\overline{\mathrm{D}(\ln E R(-2))}$ & $\begin{array}{c}0.348315 \\
(0.14247) \\
{[2.44490]}\end{array}$ & & \\
\hline$\overline{\mathrm{D}(\ln E R(-3))}$ & & & $\begin{array}{c}0.931720 \\
(0.53101) \\
{[1.75460]}\end{array}$ \\
\hline$\overline{\mathrm{D}(\ln E R(-5))}$ & & $\begin{array}{c}0.333000 \\
(0.14525) \\
{[2.29262]} \\
\end{array}$ & $\begin{array}{c}-1.165368 \\
(0.50199) \\
{[-2.32151]}\end{array}$ \\
\hline$\overline{\mathrm{D}(\ln F R(-1))}$ & $\begin{array}{c}0.106409 \\
(0.03661) \\
{[2.90680]} \\
\end{array}$ & & $\begin{array}{c}0.453587 \\
(0.13270) \\
{[3.41821]}\end{array}$ \\
\hline$\overline{\mathrm{D}(\ln F R(-5))}$ & & & $\begin{array}{c}0.264713 \\
(0.11428) \\
{[2.31636]}\end{array}$ \\
\hline$\overline{\mathrm{C}}$ & $\begin{array}{c}0.184222 \\
(0.10084) \\
{[1.82684]}\end{array}$ & $\begin{array}{c}0.258191 \\
(0.10577) \\
{[2.44107]}\end{array}$ & \\
\hline $\ln M$ & $\begin{array}{c}-0.015117 \\
(0.00822) \\
{[-1.83950]}\end{array}$ & $\begin{array}{c}-0.020893 \\
(0.00862) \\
{[-2.42399]}\end{array}$ & \\
\hline R-squared & 0.743100 & 0.437528 & 0.578961 \\
\hline Adj. R-squared & 0.643843 & 0.220209 & 0.416286 \\
\hline Sum sq. resids & 0.002452 & 0.002697 & 0.032219 \\
\hline
\end{tabular}

Note: Estimates for the short-run dynamics that are not statistically significant at the $10 \%$ level are not reported.

Based on the EC terms estimated in the model, about $16 \%$ and $31 \%$ of the long-run disequilibrium is corrected each quarter by the changes in the $\ln E R$ and the $\ln F R$, respectively. However, while the estimated EC term for $\ln E R$ is statistically significant at the 5 percent level, the one for the variable $\ln F R$ is statistically insignificant. The estimated long-run steady state also suggests that $\ln P$ and $\ln F R$ move together in the same direction in the long-run, but $\ln P$ and $\ln E R$ move in the opposite direction; both of these estimated relationships are statistically significant. In particular, if the foreign exchange reserve were to increase by 10 percent, then the inflation in China will also increase, but only marginally by 1 percent.

On the other hand, if the RMB were to appreciate by 10 percent, then inflation in China will increase by 7 percent. (Note 5) Table 7 reports the variance decomposition of $\ln P$ and the results show that $\ln E R$ explains at the maximum about 20 percent of the variation in $\ln P$, but $\ln F R$ only accounts for 3.38 percent of it at most. These results consistently indicate that changes in the exchange rate have a much greater impact on the inflation in China than the changes in the foreign reserve deposit. 
Table 7. Variance Decomposition of $\ln P$

\begin{tabular}{ccccc}
\hline Period & S.E. & $\ln P$ & $\ln E R$ & $\ln F R$ \\
\hline 1 & 0.007846 & 100.0000 & 0.000000 & 0.000000 \\
2 & 0.013477 & 94.74434 & 1.738644 & 3.517012 \\
3 & 0.017861 & 86.54770 & 8.615728 & 4.836571 \\
4 & 0.021500 & 80.96685 & 14.53974 & 4.493411 \\
5 & 0.026965 & 80.70088 & 15.97689 & 3.322228 \\
6 & 0.031962 & 80.48511 & 15.85901 & 3.655880 \\
7 & 0.035278 & 79.06009 & 16.57042 & 4.369494 \\
8 & 0.037857 & 77.86409 & 17.57149 & 4.564425 \\
9 & 0.041161 & 78.05112 & 17.56273 & 4.386156 \\
10 & 0.044283 & 77.95935 & 17.35989 & 4.680755 \\
\hline
\end{tabular}

Cholesky Ordering: $\ln P, \ln E R, \ln F R$

The estimated relationship here between $\ln P$ and $\ln F R$ is consistent with the findings reported in Chen (2011). Based on a VAR model and the results of the impulse response function, Chen concluded that the largest impact of a shock to China's foreign exchange reserve on its general price level is only 4 percent. Hence, although the tremendous amount of foreign exchange reserve that flowed into China in recent years did affect its inflation, the actual magnitude of the disturbance was in fact much less than what is generally expected. This relatively weak positive correlation between the two variables can be explained by two facts: (1) the existing economic system in China is a market economy with socialist characteristics, implying that a certain share of the planned economy of the past is still being maintained. Too much money circulating in the economy will cause inflation, but the total money supply is affected by the amount of foreign exchange reserves as well as the amount of domestic credit and loans as suggested in Lardy (2005).

When the foreign exchange reserve started to increase rapidly in recent years, the Chinese Central Government limited its impact on inflation by commanding the $\mathrm{PBoC}$ to tighten the control of domestic credit and loans, and (2) by the use of successful sterilization policies in controlling the monetary base and the money multiplier in China. To minimize the pressure of the increasing amount of foreign exchange reserve on the expansion of the monetary base, the $\mathrm{PBoC}$ has increased the amount of government bonds issued and sold to both financial and non-financial institutions. In early 1998, the authorities used treasury bonds or securities as the sterilization tools, but they have issued and traded short-term and mid-term notes to absorb capital inflows into the country since 2002. In addition, the $\mathrm{PBoC}$ also increased the required reserved ratio of all commercial banks and the usage of open market operations to reduce the value of the money multiplier. The required reserve ratio was set at 6 percent in 2006 but went up to 17.5 percent in July of 2008. (Note 6) Other measures such as increasing the benchmark interest rate, broadening the floating band of financial institutions' lending rate, and halting the non-government-approved construction loans window guidance were also used in numerous occasions. The appreciation of the Chinese currency in recent years had also helped to lower the amount of RMB required for the $\mathrm{PBoC}$ to purchase the same amount of foreign exchange reserve, and hence further lessen the impact of its increased quantity on China's monetary base and inflation.

Standard international economics theory suggests that when the currency of a country appreciates, it will discourage exports and hence reduce the demand of the domestic currency and inflation. As such, the long-run relationship between the two variables $\ln P$ and $\ln E R$ should be positive instead of negative as is shown in the estimation results depicted in Table 6. This interesting contradiction can however be explained by the reality in today's China. When looking at the changes in the exchange rate and the amount of exports in China between 1996 and 2001 (except the two-year period during the Asian financial crisis), the value of the RMB continued to appreciate during that time although there were surpluses as well as deficits in China's current account throughout the same time interval. The RMB gradually depreciated between 2002 and 2004; the exchange rate had risen during that one year, but the current account had remained relatively stable during the first twelve months of that period. It was only in 2004 that the movement in the current account had become more volatile.

In particular, the current account experienced deficit in the first few months of 2004 and then turned to surplus starting May of that year, and the magnitude of the surplus continued to increase until the end of 2004. In 2005, the RMB started to gradually appreciate again, but instead of undergoing a deficit, the current account of China had in fact encountered surplus year after year since then and the amount of surplus was also increasing. Therefore, based on these historical data, it is safe to conclude that there is no apparent negative correlation between the movements in the exchange rate and the current account balance and hence inflation in China. In 
fact, according to Zeng and Zhou (2008), the estimated correlation between the nominal exchange rate and trade balance in China between 1996 and 2007 is only a minimal 0.095. The same coefficient estimated between 2001 and 2010 using the data collected here results in a value of 0.195 and is statistically insignificant. Therefore, the seemingly counter-intuitive negative long-run relationship between $\ln P$ and $\ln E R$ as shown in Table 6 may not be that unreasonable after all.

There are also two possible explanations for the relationship, or the lack thereof, between $\ln P$ and $\ln E R$. First, it is an undisputable fact that the RMB was undervalued for many years; it is still believed that there is ample room for continued appreciation. Therefore, there exists a strong expectation around the globe that the value of the Chinese currency will keep on rising in the near future, leading to a continued inflow of speculative financial capital into China even though the exchange rate, i.e., RMB per dollar, has been gradually falling. Under this condition, if the increase in the supply of goods and services cannot match the increase in demand caused by the continuous inflow of speculative foreign monies, the result will be rises in general price levels. Second, ever since becoming a WTO member in 2001, China has been playing a bigger and bigger role in the integration of the global economy, in which each and every country is playing its share in the global division of labor. Under this new economic order, the major determining factor of the change in the trade balance of a country is no longer the exchange rate, but rather its resource endowment and comparative (and competitive) advantages in production. The continuous increase in the exports of China and therefore the demand for its currency in recent years is just a natural consequence of the global economic integration.

\section{Conclusion}

This paper studies the influences of foreign exchange reserve and exchange rate on the general price level of China based on the data collected between 1994 and 2010. Our results suggest that there is a 10 to 1 ratio between the change in China's foreign exchange reserves and its general price level. That is, if $F R$ were to increase by 10 percent, then $P$ will increase by 1 percent. The ratio, however, increases to 10 to 7 between the exchange rate and the price level. These results imply that the impact of the changes in net foreign exchange reserve has been, through careful policy, effectively neutralized by the $\mathrm{PBoC}$ under the sterilization policies of the Chinese Central Government. Hence, it appears that China is able to maintain a steady increase in the monetary base caused by the rapidly increasing foreign exchange reserves while maintaining a relatively stable price level at the same time.

The effectiveness of the sterilization policy and capital control implies that China can continue to implement its export-oriented strategy without much concern about its inflation. This is an important implication to the policy makers of China because export-led growth has been proven to be successful in raising the living standards and reducing poverty of the Chinese population over the past decades. It is estimated that 402 million people so far have been relieved out of poverty (based on a $\$ 1$ per day expenditure level) as a consequence of Chinese economic reforms (The World Bank 2003). However, as of 2008, there were still an estimated 173 million Chinese living in poverty. Export-led growth, as an intentional policy, will have to continue to play an important role in the economic development and employment strategy of China in the foreseeable future in order to see continued rising income levels and to alleviate poverty.

Of course, as a major player in the global economy, China must "play by the rules" to ensure a "level playing field" for other countries. Whether or not the RMB will revalue has also become the focus of international attention and there is a high political and economic demand for it. There is also the possibility that the cost of sterilization will become too high and will therefore be an unsustainable policy in the future. (Note 7) Unfortunately, the adoption of a purely floating exchange rate system also does not seem to be feasible. Bleaney and Fielding (2008) suggest that a floating exchange rate regime has had a significant cost for developing countries with inflation tending to be over 10 percent per annum faster than in the typical pegged-rate countries.

Our findings suggest that it would be better for the RMB to appreciate slowly and gradually rather than radically since a rapid appreciation will cause rampant inflation creating internal instability, a scenario that the Chinese Central Government will avoid at all cost. Mwase (2006) also pointed to the fact that although the decrease in inflation has been associated with a weaker exchange rate, periods of high inflation have been associated with larger changes in the exchange rate and periods of lower inflation with smaller changes in the exchange rate.

Managing slow and gradual change policy in the exchange rate will ensure a steady and healthy economic growth for the country in the future and at the same time promote the image of China as a team player. The fact that China has become "the" trading partner for most economies in the world makes it in the overall economic interest of everyone to allow a strong and stable economic development in China. 


\section{References}

Bleaney, M., \& Francisco, M. (2008). Balance Sheet Effects and the Choice of Exchange Rate Regime In Developing Countries. Journal of International Trade \& Economic Development, 17, 297-310. http://dx.doi.org/10.1080/09638190701872822

Chen, W. (2011). A Research into the Relationship among Excess Liquidity, Excessive Foreign Exchange Reserve and Inflation - Evidence from the Monthly Data of Our Country from 1997 to 2009. Journal of Economic Survey, 2, 143-147.

Dickey, D. A., \& Fuller, W. A. (1979). Distribution of the Estimations for Autoregression Time Series with a Unit Root. Journal of the American Statistical Association, 74, 427-38.

Dickey, D. A., \& Fuller, W. A. (1981). Likelihood Ratio Statistics of Autoregressive Time Series with a Unit Root. Econometrica, 49, 1057-1072. http://dx.doi.org/10.2307/1912517

Fernald, J., Hali, E., \& Loungani, P. (1998). Was China the First Domino? Assessing Links between China and the Rest of Emerging Asia. International Finance Discussion Paper (604). Federal Reserve Board. http://dx.doi.org/10.2139/ssrn.94960

Fischer, S. (2008). Mundell-Fleming Lecture: Exchange Rate Systems, Surveillance, and Advice. IMF Staff Papers, 55, 367-383. http://dx.doi.org/10.1057/imfsp.2008.12

He, X., Wu, H. Y., \& Liu, S. G. (2003). An Analysis of the Effect of RMB Exchange Rate Adjustment on China's Macroeconomy. Journal of World Economy Statistic Study, 2, 1-18.

Johansen, S. (1988). Statistical Analysis of Cointegration Vectors. Journal of Economic Dynamics and Control, 12, 231-254. http://dx.doi.org/10.1016/0165-1889(88)90041-3

Johansen, S. (1991). Estimation and Hypothesis Testing of Cointegration Vectors in Gaussian Vector Autoregressive Models. Econometrica, 59, 1551-1580. http://dx.doi.org/10.2307/2938278

Johansen, S., \& Juselius, K. (1990). Maximum Likelihood Estimation and Inference on Cointegration - with Application to the Demand for Money. Oxford Bulletin of Economics and Statistics, 52, 169-210.

Kumhof, M., Li, S. J., \& Yan, I. (2007). Balance of Payments Crises under Inflation Targeting. Journal of International Economics, 72(1), 242-264. http://dx.doi.org/10.1016/j.jinteco.2006.10.002

Lardy, N. R. (2005). Exchange Rate and Monetary Policy in China. CATO Journal, 25, 41-47.

Morrison, W., \& Labonte, M. (2008). China's Currency: Economic Issues and Options for U.S. Trade Policy. Congressional Research Service.

Mundell, R. A. (1963). Capital mobility and stabilization policy under fixed and flexible exchange rates. Canadian Journal of Economic and Political Science, 29, 475-485. http://dx.doi.org/10.2307/139336

Mwase, N. (2006). An Empirical Investigation of the Exchange Rate Pass-Through to Inflation in Tanzania. IMF Working Papers, 06(150).

People's Bank of China. (2008). China: The Evolution of Foreign Exchange Controls and the Consequences of Capital Flows. In S. Bank for International (Ed.). Financial Globalisation and Emerging Market Capital Flows. BIS Papers, 44, 143-151.

The World Bank. (2003). China: Promoting Growth with Equity. No. 24169-CHA, Washington DC.

Toda, H. Y., \& Yamamoto, T. (1995). Statistical Inferences in Vector Autoregressions with Possibly Integrated Processes. Journal of Econometrics, 66, 225-250. http://dx.doi.org/10.1016/0304-4076(94)01616-8

Yang, J., Yin, H. Y., \& He, H. (2007). The Chinese Currency: Background and the Current Debate. International Journal of Public Administration, 30, 117-135. http://dx.doi.org/10.1080/01900690601112946

Zeng, L., \& Zhou, Q. W. (2008). An Econometric Analysis of the Effect of RMB Appreciation on CPI. Journal of Shanghai Finance, 10, 70-74.

\section{Notes}

Note 1. The official rate prevailing just before unification was 5.8 RMB per US dollar.

Note 2. For details, see People's Bank of China (2008).

Note 3. See http://www.safe.gov.cn/model_safe_en/glnb_en/glnb_list_en.jsp.

Note 4. See http://www.pbc.gov.cn/publish/english/958/index.html. 
Note 5. ER is expressed as RMB per US dollar. As such, the RMB appreciates when ER decreases.

Note 6. Details of the sterilization policies used by the $\mathrm{PBoC}$ in recent years to maintain domestic stability can be found in $\mathrm{He}$ (2005) and PBoC (2008).

Note 7. See Wang (2010) for details of this argument. 